\title{
RESPONSABILIDADE SOCIAL CORPORATIVA, SOLIDARIEDADE E DÁDIVA: \\ O caso da Petrobras S.A.
}

Dissertação de Mestrado

Dissertação apresentada como requisito parcial para a obtenção do grau de Mestre pelo Programa de Pós-graduação em Administração do Departamento de Administração da PUC-Rio

Orientadora: Prof. Dra. Patricia A Tomei

Co-Orientador: Prof. Dr. José Roberto Gomes da

Silva

Rio de Janeiro

Fevereiro de 2004 
Todos os direitos reservados. É proibida a reprodução total ou parcial do trabalho sem a autorização prévia da universidade, da autora e da orientadora.

\section{Luciana Poli Silva}

Graduou-se em Administração na UFRJ (Universidade Federal do Rio de Janeiro) em 1996. Cursou o programa de pós-graduação em Recursos Humanos do Instituto de Administração e Gestão da PUC-Rio em 1998. Sua área de interesse acadêmico é Organizações. Possui oito anos de experiência profissional em Recursos Humanos.

Ficha Catalográfica

Silva, Luciana Poli

Responsabilidade social corporativa, solidariedade e dádiva: o caso da Petrobras S.A. / Luciana Poli Silva ; orientadora: Patrícia A Tomei ; co-orientador: José Roberto Gomes da Silva. - Rio de Janeiro : PUCRio, Departamento de Administração, 2004.

143 f. : il. ; $30 \mathrm{~cm}$

Dissertação (mestrado) - Pontifícia Universidade Católica do Rio de Janeiro, Departamento de Administração.

Inclui referências bibliográficas

1. Administração - Teses. 2. Responsabilidade social corporativa. 2. Dádiva. 3. Solidariedade. I. Tomei, Patricia A. II. Silva, José Roberto Gomes da. III. Pontifícia Universidade Católica do Rio de Janeiro. Departamento de Administração. IV. Título. 


\section{RESPONSABILIDADE SOCIAL CORPORATIVA, SOLIDARIEDADE E DÁDIVA: \\ O caso da Petrobras S.A.}

Dissertação apresentada como requisito parcial para a obtenção do grau de Mestre pelo Programa de Pós-graduação em Administração do Departamento de Administração da PUC-Rio. Aprovada pela Comissão Examinadora abaixo assinada.

Profa. Patrícia Amélia Tomei Orientadora Departamento de Administração, PUC-Rio

Prof. José Roberto Gomes da Silva Co-orientador Departamento de Administração, PUC-Rio

Profa. Adriana Victoria Garibaldi de Hilal COPPEAD, UFRJ

Profa. Danilo Marcondes de Souza Filho Departamento de Filosofia, PUC-Rio

Prof. João Pontes Nogueira Vice-Decano de Pós-Graduação do CCS 
Aos meus pais, Newton e Dinah, e aos meus irmãos, Gustavo e Carolina, pelo imenso amor, zelo constante e exemplo de vida que, continuamente, me dão. 


\section{Agradecimentos}

À minha orientadora, Prof. Dra. Patricia A. Tomei, pelo estímulo e confiança.

Ao meu co-orientador, Prof. Dr. José Roberto Gomes da Silva, pelo acompanhamento e apoio.

A todos os entrevistados, que tornaram possível a realização deste trabalho.

Aos meus colegas da PUC-Rio, que contribuíram para que o meu curso de Mestrado fosse uma rica experiência.

A todos os professores e funcionários do Departamento, pelos ensinamentos e pelo suporte. 


\section{Resumo}

Poli Silva, Luciana; Tomei, Patricia A.; Da Silva, José Roberto Gomes Responsabilidade Social Corporativa, Solidariedade e Dádiva: $O$ caso da Petrobras S.A. Rio de Janeiro, 2004. 135 p. Departamento de Administração, Pontifícia Universidade Católica do Rio de Janeiro.

A responsabilidade social corporativa no Brasil tem se tornado um tema de estudo recorrente no campo da Administração. Entretanto, um aspecto crítico relacionado ao assunto deve ser analisado com maior profundidade: no que se baseia o modelo de gestão social das empresas no Brasil? Acreditamos que o aporte de concepções de outras disciplinas, como a Sociologia e a Antropologia, pode contribuir para o entendimento mais amplo da questão. Trouxemos para a pesquisa teórica os estudos do etnógrafo Marcel Mauss sobre o dom, ou paradigma da dádiva, e a sua releitura por modernos teóricos, bem como diferentes abordagens relacionadas à solidariedade. Este trabalho objetiva analisar até que ponto a gestão da responsabilidade social corporativa no Brasil pode ser associada aos princípios da dádiva e da solidariedade. Para cumprir tal objetivo, além da pesquisa teórica, foi realizado um estudo de caso de uma organização de economia mista que atua em projetos sociais em diversos estados do país, a Petrobras S.A. De acordo com o paradigma da dádiva, as relações sociais se compõem pelos pólos do interesse, da obrigação, do prazer e da espontaneidade. $\mathrm{Na}$ presente pesquisa, observamos que os quatro pólos do dom estão presentes na gestão da responsabilidade social corporativa da empresa estudada, em graus que variam de acordo com a especificidade de cada projeto social. Notamos também que a concepção de solidariedade, intrinsicamente relacionada à interdependência, está no cerne da gestão da responsabilidade social corporativa, ainda que os atores sociais envolvidos, em sua maioria, a associem a uma prática assistencialista.

\section{Palavras-chave}

Responsabilidade social corporativa; dádiva; dom;solidariedade. 


\section{Abstract}

Poli Silva, Luciana; Tomei, Patricia A.; Da Silva, José Roberto Gomes Social Corporate Responsibility, Solidarity and Gift: the case of Petrobras S.A. Rio de Janeiro, 2004. 135 p. MSc. Departamento de Administração, Pontifícia Universidade Católica do Rio de Janeiro.

The social responsibility of business has become an usual theme of study in Brazil in the Business Administration area. However, a critical aspect related to the subject should be analyzed in deep: what is the basis of the model of corporate social management in Brazil? We believe that conceptions of other disciplines, such as Sociology and Anthropology, may contribute to a wider understanding of the subject. Therefore, we used in the theoretical research the studies of the ethnographer Marcel Mauss about the gift, and its modern interpretation, as well as a variety of conceptions related to solidarity. The main objective of this research is to analyze if the management of corporate social responsibility can be related to the principles of the gift and solidarity. To achieve this goal, in addition to the theoretical research, a case study of an organization that develops social programs throughout the country was made. The company studied is Petrobras S.A. According to the gift, the social relations are formed by the poles of interest, obligation, pleasure and spontaneity. In this study, we observed that the four poles of the gift exist in the management of the corporate social responsibility of the company analyzed, in degrees that vary according to the specificity of each project. We also noted that the conception of solidarity, intrinsically related to mutual-dependency, is central in the management of corporate social responsibility, despite the fact that the social actors involved, in majority, associate it to a philanthropic practice.

\section{Keywords}

Corporate social responsibility, gift, solidarity. 


\section{Sumário}

1 O Problema

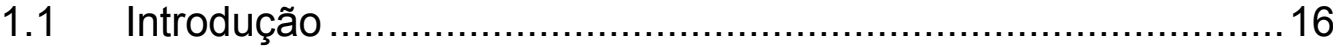

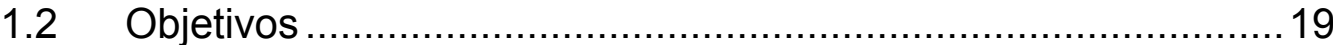

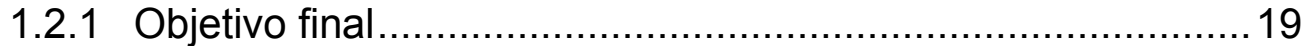

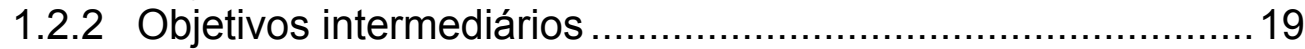

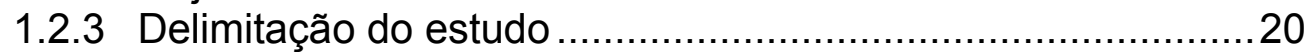

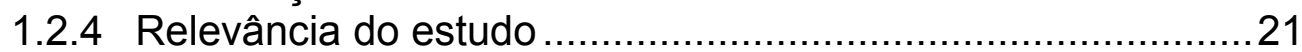

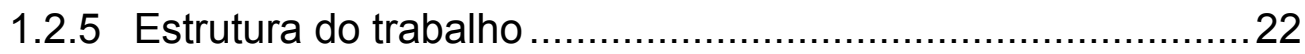

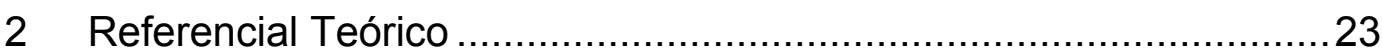

2.1 O Homem, a sociedade e a solidariedade ..............................23

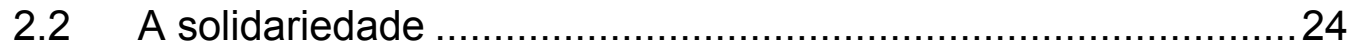

2.3 A solidariedade e a competitividade empresarial ........................31

$2.4 \quad$ Solidariedade $X$ filantropia empresarial.....................................34

2.5 Outros Conceitos de atuação social das empresas ......................36

2.5.1 Responsabilidade social corporativa .....................................3

2.5.2 Responsabilidade social corporativa no Brasil ........................38

2.5.3 Responsabilidade social na visão acadêmica .......................41

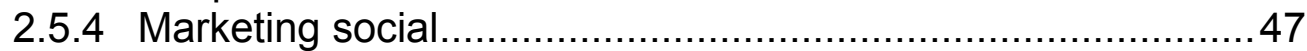

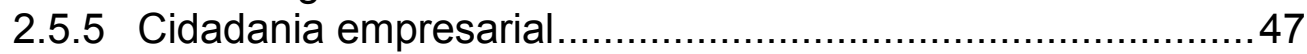

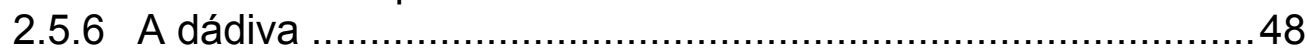

2.5.7 A dádiva, a responsabilidade social e a solidariedade ...........60

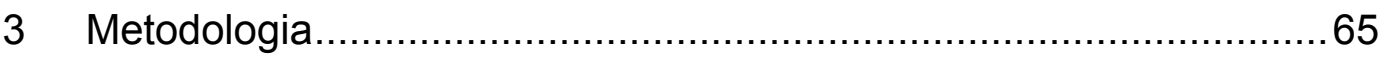

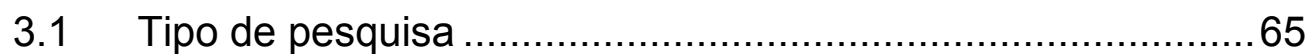

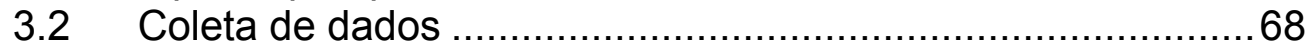

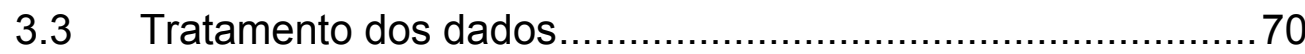

3.4 Limitações do método ....................................................

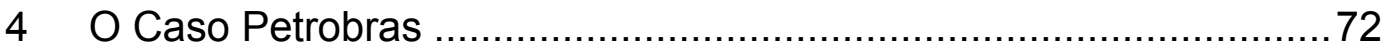

4.1 Histórico da Petrobras .....................................................

4.2 Histórico da atuação social da Petrobras ..............................74

4.3 Novas diretrizes para a atuação social da Petrobras ..............75

4.4 Resumo dos projetos sociais estudados ..............................78

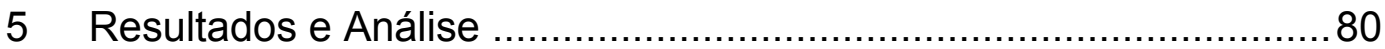

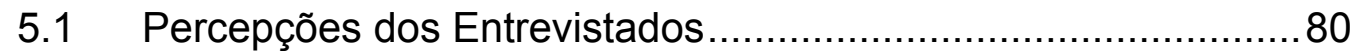

5.1.1 Histórico de atuação social da Petrobras .............................. 80

5.1.2 A responsabilidade social na empresa após a implantação do

Programa Petrobras Social ....................................................... 82

5.1.3 A interdependência dos atores sociais ............................... 86 
5.1.4 As trocas e os benefícios percebidos pelos atores sociais envolvidos nas ações de responsabilidade social da petrobras.........89

5.2 Análise dos Resultados

6 Conclusão 102

7 Sugestões para futuras pesquisas 106

8 Bibliografia 107

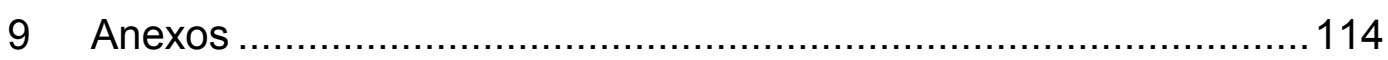

9.1 Anexo A - Recordes de produção da Petrobras ......................114

9.2 Anexo B - Dados da Petrobras ……………….................115

9.3 Anexo C - Roteiro para a elaboração de projetos .....................118

9.4 Anexo D - Perfil dos projetos sociais estudados .....................135

9.5 Anexo E - Roteiros das entrevistas .......................................138

9.6 Anexo F - Carta Petrobras Fome Zero .................................. 142 


\section{Lista de Figuras}

Figura 1 - Os Quatro Pólos da Dádiva e a complexidade das relações

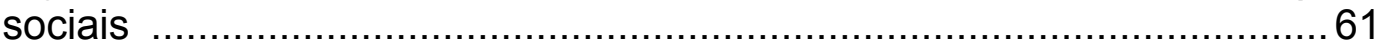

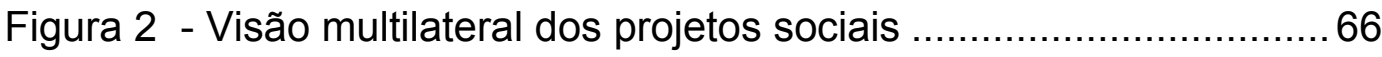




\section{Lista de Tabelas}

Tabela 1 - Quadro resumo dos entrevistados em os projetos sociais estudados ...................................................................................... 67

Tabela 2 - Relação dos projetos sociais estudados ............................ 79

Tabela 3 - Recordes de produção de petróleo da Petrobras.................. 114

Tabela 4 - Dados da Petrobras referentes ao ano de 2002 ..................115

Tabela 5 - Evolução histórica da produção nacional de óleo condensado e LGN. 
Seu dotô vô li dizê,

Isso num é pabuláge.

Nóis vivia bem tranquilo, Aqui pur'essas paráge.

Foi quando apareceu

Essa tá de PETROBÁGE

Dizeno: "- A terra é sua,

Porém o qui tá imbaxó,

Lá nos canto mais profundo,

Qui num dá nem frô nem cácho.

Isso é coisa da Nação,

Só prefurando é qu'eu acho."

Feiz eu assiná uns papé,

Chamando de liberação.

Prometeu pagá a nóis,

As lavôra lá do chão.

E inda disse mais assim:

"-Pro ano tem Seividão."

Paga e nóis acha pôco,

Qui a nossa vida é tão dura.

Nóis vivemo num sufoco,

Parece inté ditadura.

E os roiáti só vem,

Pros Istado e as Prefeitura.

Im riba desses roiáti,

Digo sem assombração,

A PETROBÁGE divia,

Fazê fiscalização.

Pros Istado e as Prefeitura, Invisti na Região.

Se um pôço num desse ólio, Qui li interessa, de vez. Dêxasse ele dando água, Pur anos, dias ou mês. Pra nóis prantá aguado, Pra alimentá vocês.

No nosso Nordeste seco, Num era nada dimais.

Dez ou vinte produzindo, Muito ólio ou mermo gáiz. Só um pôço dando água, Interessa muito mais! 
Tô falando do passado, Isso foi antigamente.

Hoje tá tudo mudado

E tá munto diferente.

Nóis vive é tudo surrindo,

Chega amostramo os dente.

A PETROBÁGE mudô, Agora mostra o que diz.

Quando um poço num dá ólio, Pra vê a gente filiz,

Junto com as cumunidade Já fez muito chafariz.

Hoje a coisa miorô,

Mudô da água pro vinho.

Pois desde noventa e oito

Aclareáro os caminho.

Tão recebendo os roiáti,

Pai, fili, irmão, vizinho.

Nossa vida miorô,

Despois que vêi os roiáti.

Tem quem deixô as canoa

Pensando em comprá iáte.

Tem ôtros que véve inté

De casa para as buáte.

Arguns já mudáro bem, Já fizéro casa nova, Compráro carro do ano,

Tão cantando bossa-nova, Investiro no comérço

E dão uma de Casanova.

Eu vô dexá de cunversa, Dexá de falá bobáge,

De canta góga, premessa,

$E$ de arrotá vantáge.

Viva o povo brasilêro!

Viva a nossa PETROBÁGE!!!

* Antônio Kydelmir Dantas de

Oliveira. (Empregado da

Petrobras)

Fonte: Almanaque memória dos trabalhadores Petrobras. Rio de Janeiro: Petrobras 2003 